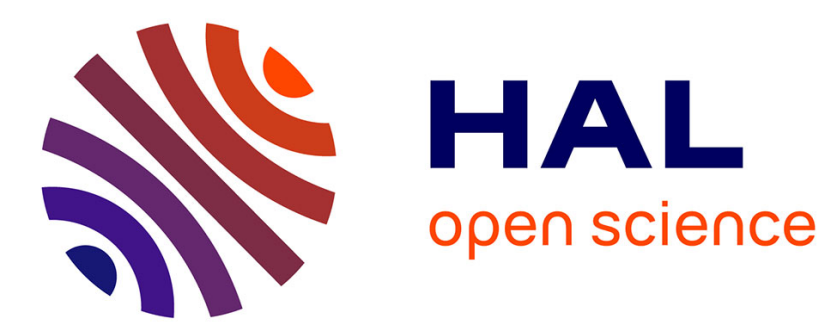

\title{
Manufacturing Brick from Attapulgite Clay at Low Temperature by Geopolymerization
}

Mouhamadou Bassir Diop, Laurent Molez, Ahmed Bouguerra, Arona

Ndofféne Diouf, Michael W. Grutzeck

\section{- To cite this version:}

Mouhamadou Bassir Diop, Laurent Molez, Ahmed Bouguerra, Arona Ndofféne Diouf, Michael W. Grutzeck. Manufacturing Brick from Attapulgite Clay at Low Temperature by Geopolymerization. Arabian Journal for Science and Engineering, 2014, 39 (6), pp.4351-4361. 10.1007/s13369-014-1007-9 . hal-01005503

\section{HAL Id: hal-01005503 \\ https://hal.science/hal-01005503}

Submitted on 4 Dec 2019

HAL is a multi-disciplinary open access archive for the deposit and dissemination of scientific research documents, whether they are published or not. The documents may come from teaching and research institutions in France or abroad, or from public or private research centers.
L'archive ouverte pluridisciplinaire HAL, est destinée au dépôt et à la diffusion de documents scientifiques de niveau recherche, publiés ou non, émanant des établissements d'enseignement et de recherche français ou étrangers, des laboratoires publics ou privés. 


\title{
Manufacturing Brick from Attapulgite Clay at Low Temperature by Geopolymerization
}

\author{
Mouhamadou Bassir Diop - Laurent Molez · Ahmed Bouguerra · Arona \\ Ndofféne Diouf · Michael W. Grutzeck
}

\begin{abstract}
Ground to approximately 250-mesh size powder, attapulgite mining waste was mixed with different alkali concentrations $(4,8$ and $12 \mathrm{M} \mathrm{NaOH})$ to form thick paste and statically compacted ( $10 \mathrm{MPa})$. The samples were cured at $40^{\circ} \mathrm{C}$ and $60 \% \mathrm{RH}$ for long-term storage ( 1 week-3 months) and at $120^{\circ} \mathrm{C}$ and $0 \% \mathrm{RH}$ for short-term storage of varying periods of time (6,12 and $24 \mathrm{~h})$. This particular clay was characterized using a variety of techniques including physical (DTA, X-ray, laser granulometry, microstructure, PSD, etc.) and chemical analysis. The main minerals present are palygorskite, quartz, calcite and hematite. DTA/TGA curves resemble those obtained when a sample of kaolin is first heated and then cooled. When treated with $12 \mathrm{M}$-alkali solutions and cured for 7 days at $80^{\circ} \mathrm{C}$, the minerals present are montmorillonite, larnite, stilbite, dolomite and calcite. Palygorskite clay disappeared after the reaction. In long-term tests, strength did not increase with time for attapulgite clays activated with sodium hydroxide. For all concentrations and periods, the strength obtained with $8 \mathrm{M}$ concentration was greater. In short-term tests, the maximum strength was obtained after $24 \mathrm{~h}$ for $12 \mathrm{M}$ concentrations. After $12 \mathrm{~h}$ of curing, alkali activation of attapulgite at $120^{\circ} \mathrm{C}$ appears to be much more advantageous in terms of strength. The fiber structure of the attapulgite disappeared and was completely changed into one resembling plates. The low conductivity obtained suggests that the Na component of the 8 and $12 \mathrm{M}$ brick reacts nearly completely.
\end{abstract}

Keywords Sun-dried bricks; Clay; Alkali-activated; Geopolymer; Durability; Attapulgite

M. B. Diop · M. W. Grutzeck

Materials Research Laboratory, Materials Research Institute (MRI), The Pennsylvania State University, University Park, PA 16802, USA

M. B. Diop

Faculté des Sciences et Techniques, Institut des Sciences de la Terre (IST), Université Cheikh Anta Diop de Dakar, BP 5396, Dakar, Senegal e-mail: mbdiop@ucad.sn; mbassirdiop@yahoo.fr

L. Molez

Laboratoire de Génie Civil et Génie Mécanique (LGCGM)-EA 3913, Institut National des Sciences Appliquées, Université

Européenne de Bretagne, 20 avenue des buttes de Coësmes, CS 70839, 35508 Rennes Cedex 7, France

\author{
A. Bouguerra \\ 31, rue Mirabeau, Résidence Edgar-Degas, 35000 Rennes, France \\ N. Diouf \\ Department of Natural Resources and Environmental Design, North Carolina Agricultural and Technical State University, 224A \\ Carver Hall, Greensboro, NC 27411, USA
}




\section{Introduction}

Since its installation in 1986, Allou Kagne's attapulgite treatment unit has produced large quantities of "fine grains" considered as waste, as opposed to the main product whose grain size is between 0.5 and $6.3 \mathrm{~mm}$. These fine grain sizes of $0-3 \mathrm{~mm}$ are associated with an oversized component $(>6.3 \mathrm{~mm})$. The reserve is roughly estimated at 1,300,000 tons, and divided into three great stacks. From one pile to another, the material remains homogeneous with an average calcium carbonate (CaCO3) content equal to $10 \%$. A previous study on drilling mud has shown that this waste remains stable despite variations in the physico-chemical condition of the medium and can be used to fabricate good quality drilling mud [1].

Clay-based bricks are generally used in Senegal and in most Equatorial African regions for building. However, they have one major problem, which is their low weathering resistance. During the rainy season, these bricks undergo a softening process. Their durability becomes less than 2 years. In this study, our research focuses on the development of more durable bricks using the Allou Kagne attapulgite deposit in western Senegal. This clay reserve belongs to the series of Cap Rouge, which constitutes the stratigraphical level of the top of the Horst of Ndiass, dating from the end of the Cretaceous period. Petrographic analyses indicate that this clay is homogeneous with a gray colour. Our study explores the possibility of using such material to make bricks for social housing.

Clay is one of the oldest building materials on Earth, among other ancient, naturally occurring geologic materials, such as stone and organic materials like wood. Over half of the world's population, in less developed countries, still live or work in buildings made with clay as an essential part of their load-bearing structure [2-5].

Sun-dried mud bricks are the world's oldest manufactured building material and they have stood the test of time. As testimony of sun-dried mud bricks' strength and durability, the Great Wall of China (210 BC) was built of both burned and sun-dried mud bricks. Being warm in winter and cool in summer, sun-dried mud brick houses are very energy efficient [6]. The thick, solid walls of a sun-dried mud brick home act as a buffer to weather extremes during both winter and summer. The sun-dried mud brick walls absorb sound and reduce echo, producing a home that is quiet and serene. Whether by a professional brick layer or a novice, sun-dried mud bricks are easy to lay [7]. Being made from natural materials and requiring very little energy to produce, sun-dried mud bricks are an environmentally sound choice [8].

Attapulgite clays are a composite of smectite and palygorskite. Smectites are expanding lattice clays that are more commonly known under the generic name of bentonite [9]. The palygorskite component [10] has an acicular bristle-like crystalline form, which does not swell or expand. Attapulgite forms gel structures in fresh and salt water by establishing a lattice structure of particles connected through hydrogen bonds. Attapulgite, unlike bentonite, will form gel structures in salt water and is used in special salt water drilling mud for drilling formations contaminated with salt. Palygorskite particles can be considered as charged particles with zones of + and - charges. It is the bonding of these alternating charges that allows them to form gel suspensions in salt and fresh water. Its ideal molecular formula is $(\mathrm{Mg}, \mathrm{Al})_{2} \mathrm{Si} 4 \mathrm{O} 10(\mathrm{OH}) \cdot 4(\mathrm{H} 2 \mathrm{O})$. The attapulgite clays of Allou Kagne are used to make bricks by geopolymerization. The attapulgite mining waste of Allou Kagne was mixed with different alkali concentrations to form thick paste, statically compacted and cured for varying periods of time. The contents of the mixture are given in Table 1.

Geopolymers are chains or networks of aluminosilicate mineral molecules linked with co-valent bonds. Different geopolymers can be identified according to their molecular units [11-13]:

(-Si-O-Al-O-) polysialate with $\mathrm{SiO}_{2} / \mathrm{Al}_{2} \mathrm{O} 3$ ratio equal to 2,

$(-\mathrm{Si}-\mathrm{O}-\mathrm{Al}-\mathrm{O}-\mathrm{Si}-\mathrm{O}-)$ polysialatesiloxo with $\mathrm{SiO}_{2} / \mathrm{Al}_{2} \mathrm{O}_{3}=4$,

$(-\mathrm{Si}-\mathrm{O}-\mathrm{Al}-\mathrm{O}-\mathrm{Si}-\mathrm{O}-\mathrm{Si}-\mathrm{O}-)$ polysialatedisoloxo with $\mathrm{SiO} 2 / \mathrm{Al}_{2} \mathrm{O} 3=6$.

Geopolymers can be obtained from clay [14-16]. Alkali activation of metakaolin and Class F fly ash is well known [11,17-21]. Alkali hydroxide disintegrates the solid network to produce small reactable silicate and aluminate species. The aluminosilicate kaolinite reacts with $\mathrm{NaOH}$ at $100-150^{\circ} \mathrm{C}$ and polycondenses into hydrosodalite-based geopolymer $\left(\mathrm{SiO}_{2} / \mathrm{Al}_{2} \mathrm{O}_{3}=2\right)$. A polysialatesiloxo $\left(\mathrm{SiO}_{2} / \mathrm{Al}_{2} \mathrm{O}_{3}=4\right)$ is obtained from metakaolin and $\mathrm{NaOH}$. These inorganic polymers have a chemical composition somewhat similar to zeolite A 
(Na12 [( $\left.\left.\mathrm{AlO} 2) 12\left(\mathrm{SiO}_{2}\right) 12\right] \cdot{ }_{2} 2 \mathrm{H} 2 \mathrm{O}\right)[19,20]$, but exist as amorphous solids rather than having a crystalline microstructure [22,23].

Geopolymer binders possess many advanced properties, such as fast setting and hardening, excellent bond strength [11], long-term durability, and better fire and acid resistance [24-26]. Due to such superior properties, geopolymers have the potential to be used in several industrial applications [27]. The most important advantage of geopolymer binders is their low manufacturing energy consumption and low $\mathrm{CO} 2$ emission [27-29], which makes them a "green material" [30-32]. The original raw material used by Davidovits was pure metakaolinite, activated by alkali hydroxide and/or alkalisilicate [11,28,29]. Many researchers [27,33-36] have demonstrated that several other aluminosilicate materials could be used as raw materials for geopolymers, such as fly ash, furnace slag, silica fume, kaoline, as well as some natural minerals. Xu and Van Deventer [27] investigated geopolymerization of 16 natural aluminosilicate minerals with the addition of kaolinite. It was found that a wide range of natural alumino-silicate minerals provided potential sources for synthesis of geopolymers.

The purpose of this study is to investigate the feasibility of adding sodium hydroxide to the basic mixture of Allou Kagne clay and water as a way of improving the resulting durability of clay-based bricks [26,27,37-39]. It was anticipated that such additions might also increase the strength and durability of clay bricks without significantly altering the brick-making process [40-43].

Chemical analyses have shown that the ratio $\mathrm{SiO}_{2} / \mathrm{Al}_{2} \mathrm{O} 3$ is around 10 [44]. It suggests that geopolymers can be obtained from this clay by adding $\mathrm{NaOH}$. Several studies [37,45-50] have shown that reactivity of clay can be increased by thermal treatment. However, in previous studies $[40,51,52]$, we have shown that it can be possible to obtain durable bricks from clay without thermal treatment.

In our investigation, the attapulgite clay was ground to approximately 250-mesh size powder and then mixed with different alkali concentrations (4, 8 and $12 \mathrm{M} \mathrm{NaOH}$ ) to form a thick paste. After vigorous hand-mixing, the treated clay was statically compacted in a $2.5 \mathrm{~cm}$ diameter cylinder. The compaction was carried out by a hand-operated hydraulic press. Pressure was applied until water began to be squeezed out of the sample. Pressures were typically in the $10 \mathrm{MPa}$ range. The cylinders were trimmed to $5.0 \mathrm{~cm}$ in length and then allowed to sit overnight at room temperature before being cured at two different temperatures ( 40 and $120^{\circ} \mathrm{C}$ ). This so-called "soaking" is typically used to allow time for dissolution and for geopolymer precursors to form $[44,53]$. The $40^{\circ} \mathrm{C}$ samples were cured in a "walk-in" chamber that was maintained at $60 \%$ relative humidity. The $120^{\circ} \mathrm{C}$ samples were cured in sealed Parrtype vessels fitted with Teflon liners at $120^{\circ} \mathrm{C}$ for varying periods of time (6, 12, $24 \mathrm{~h})$. Monoliths made in this way are generally very strong and highly insoluble [14,19,54-58]. 
Table 1 Formulations studied

\begin{tabular}{lllll}
\hline Sample & Tuff (wt\%) & $\mathrm{NaOH}(\mathrm{wt} \%)$ & Cure temperature $\left({ }^{\circ} \mathrm{C}\right)$ & Cure time (days) \\
\hline 1 & 80 & $4 \mathrm{M}(20)$ & 120 & 0.25 \\
2 & & & & 0.5 \\
3 & & & 40 & 1 \\
4 & 80 & $4 \mathrm{M}(20)$ & 40 & 7 \\
5 & & & & 24 \\
6 & & & 28 \\
7 & & & 60 \\
8 & & & & 90 \\
9 & 80 & $8 \mathrm{M}(20)$ & 120 & 0.25 \\
10 & & & & 0.5 \\
11 & & & & 1 \\
12 & 80 & $8 \mathrm{M}(20)$ & 40 & 7 \\
13 & & & & 24 \\
14 & & & & 28 \\
15 & & & & 60 \\
16 & & & 90 \\
18 & 80 & $12 \mathrm{M}(20)$ & 120 & 0.25 \\
19 & & & & 0.5 \\
20 & & & & 1 \\
21 & 80 & $12 \mathrm{M}(20)$ & 40 & 7 \\
22 & & & & 24 \\
23 & & & & 28 \\
24 & & & & 60 \\
25 & & & 90 \\
\hline
\end{tabular}

Diop M.B., Molez L., Bouguerra A., Diouf A.., Grutzeck M.W., Arabian Journal for Science Engineering (2014) 39:4351-4361, DOI 10.1007/s13369-014-1007-9 


\section{Experimental Program}

\subsection{Available Raw Materials}

Varieties of clay, highly weathered rock (laterites, tuffs) and mining waste (aluminum phosphate, calcium phosphate, phosphor gypsum) are materials available in Senegal for making brick. The clay reported here is more or less typical of the materials available to rural persons that make their own bricks and then use it to build their homes.

\subsection{Characterization of the Attapulgite}

The attapulgite contained in Allou Kagne clay was characterized using a variety of techniques, including chemical (Table 2) and physical analyses. Silicium oxides are the main component ( $44.9 \%$ in weight), as well as a few aluminium oxides (4.2\%). Compositional data for attapulgite clay have been plotted on a ternary diagram for the system $\mathrm{CaO}-\mathrm{Al}_{2} \mathrm{O}_{3}-\mathrm{SiO}_{2}$ along with the zeolite domain (Fig. 2b).

Particle size was determined by laser granulometry (Fig. 1a). Attapulgite clay is extremely fine ( $D \max <100 \mu m)$, with an average grain size equal to $\sim 5 \mu \mathrm{m}$.

Thermal gravimetric analysis (TGA) and differential thermal analysis (DTA) data for the attapulgite are presented in Fig. 2. This curve is typical of palygorskite mineral [16,59-61]. This figure shows four distinct endotherms:

- the first prominent one at $110^{\circ} \mathrm{C}$ due to the elimination of absorbed and zeolitic water;

- the second at $\sim 230^{\circ} \mathrm{C}$ can be attributed to the loss of hydration water;

- the third and the fourth are complex with two overlapping endotherms at $\sim 390$ and $\sim 450^{\circ} \mathrm{C}$ corresponding to the loss of coordinated water [61,62].

- a faint exotherm, centering at about $850^{\circ} \mathrm{C}$, could be observed. It can be assigned to the phase transformation of the clay to enstatite (MgSiO3).

Table 2 Chemical composition of Allou Kagne attapulgite clay (wt \%)

\begin{tabular}{|c|c|c|c|c|c|c|c|c|c|c|}
\hline $\mathrm{SiO}_{2}$ & $\mathrm{CaO}$ & $\mathrm{Al}_{2} \mathrm{O}_{3}$ & $\mathrm{Fe}_{2} \mathrm{O}_{3}$ & MgO & $\mathrm{K}_{2} \mathrm{O}$ & $\mathrm{Na} 2 \mathrm{O}$ & $\mathrm{TiO}_{2}$ & MnO & $\mathrm{P}_{2} \mathrm{O}_{5}$ & LOI \\
\hline 44.9 & 9.65 & 4.2 & 2.43 & 10.3 & 0.3 & 0.06 & 0.22 & 0.01 & 0.54 & 27.39 \\
\hline
\end{tabular}

(a)

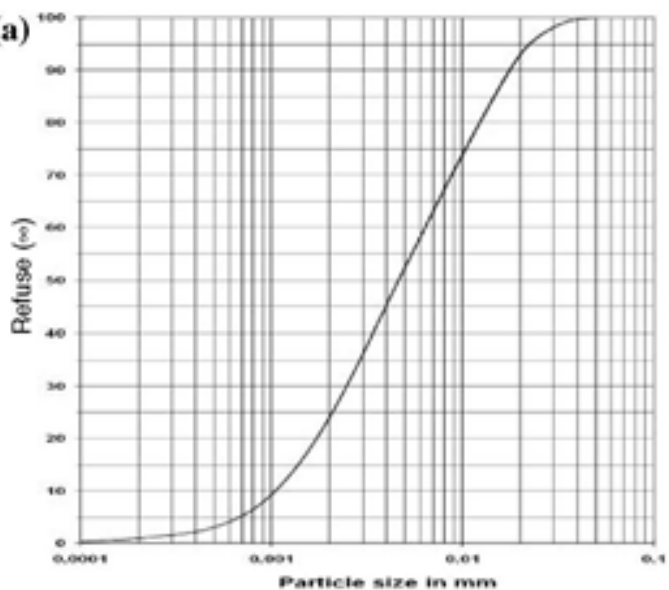

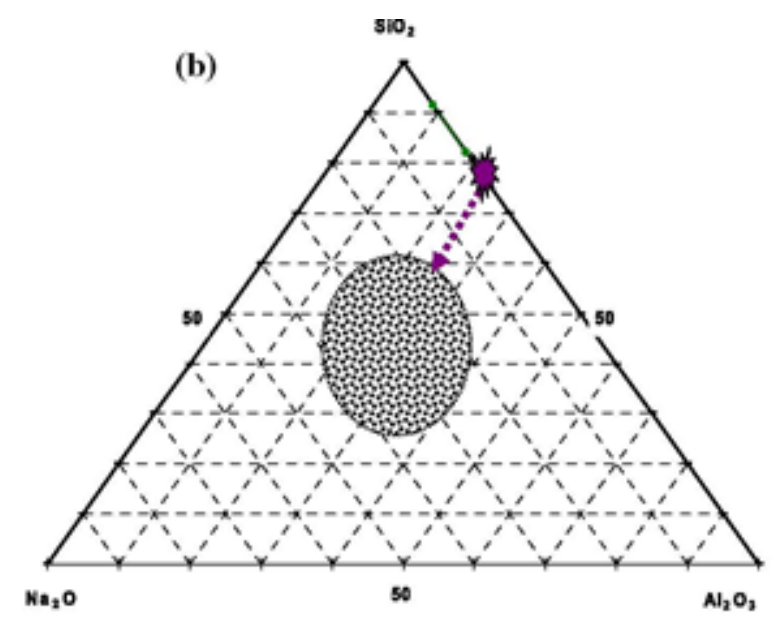

Fig. 1 View a particle size analysis suggests that the natural sample and the ultrasound treated sample are similar. View b represents the location of the attapulgite clay and the zeolite domain (center) 


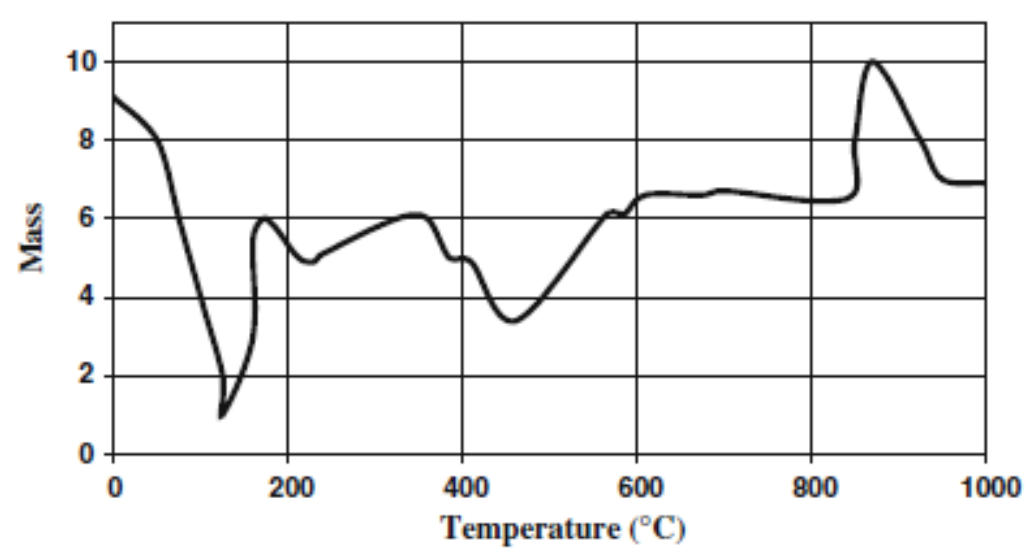

Fig. 2 DTA/TGA data for the attapulgite

SEM observations of attapulgite clay were conducted. Figure 5a presents the typical microstructure of the attapulgite clay at high magnifications $(10,000 \times)$. X-ray diffraction was used for phase analysis.

\subsection{Mechanical Tests}

After different periods of curing, the mechanical behaviors of two cylinders were tested. Because the reaction kinetics at $120^{\circ} \mathrm{C}$ was significantly greater than at $40^{\circ} \mathrm{C}$, the compressive strength values were measured after 6 , 12 and $24 \mathrm{~h}$ for the samples cured at $120^{\circ} \mathrm{C}$. For samples cured at $40^{\circ} \mathrm{C}$, cylinders were tested after $7,14,28$, and 60 days. In a previous study [51] with low temperature brick samples, we have shown that a $24 \mathrm{~h}$ curing period at $120^{\circ} \mathrm{C}$ helps achieve strengths equivalent to the strengths measured after 28 days of curing at $40^{\circ} \mathrm{C}$.

\subsection{Durability Tests}

To test durability, pieces of three samples cured at $120^{\circ} \mathrm{C}$ for $12 \mathrm{~h}$ were ground to the particle size ranging from 75 to $150 \mu \mathrm{m}$ and then dried at $105^{\circ} \mathrm{C}$. One gram of each of the powdered specimens was placed in $10 \mathrm{~mL}$ of deionized water and maintained at $90^{\circ} \mathrm{C}$ for 1 and 7 days in a sealed Teflon container. This test is a modified product consistency test (PCT) designed to test glass leaching [63]. These samples were chosen because it was assumed that reaction had reached the greatest degree at $120^{\circ} \mathrm{C}$ and leaching of these samples would better reflect what would happen to all bricks that had been cured for a longer period of time once it was used to build a house (many years). Durability tests were not conducted on the $40^{\circ} \mathrm{C}$ cured specimens because this temperature is close to the ambient temperature in Senegal. 


\section{Results}

\subsection{Mechanical Tests}

Compressive behavior of the $2.5 \mathrm{~cm} \times 5.0 \mathrm{~cm}$ cylinders was good: all breaks exhibited a typical double pyramidal shape. Typical stress-strain curves for attapulgite clay samples made with 4, 8 and $12 \mathrm{M} \mathrm{NaOH}$ solutions, and cured at $40^{\circ} \mathrm{C}$ for 28 days and $12 \mathrm{~h}$ at $120^{\circ} \mathrm{C}$, are given in Fig. 3 . The stress-strain curves indicate that the rupture is progressive.
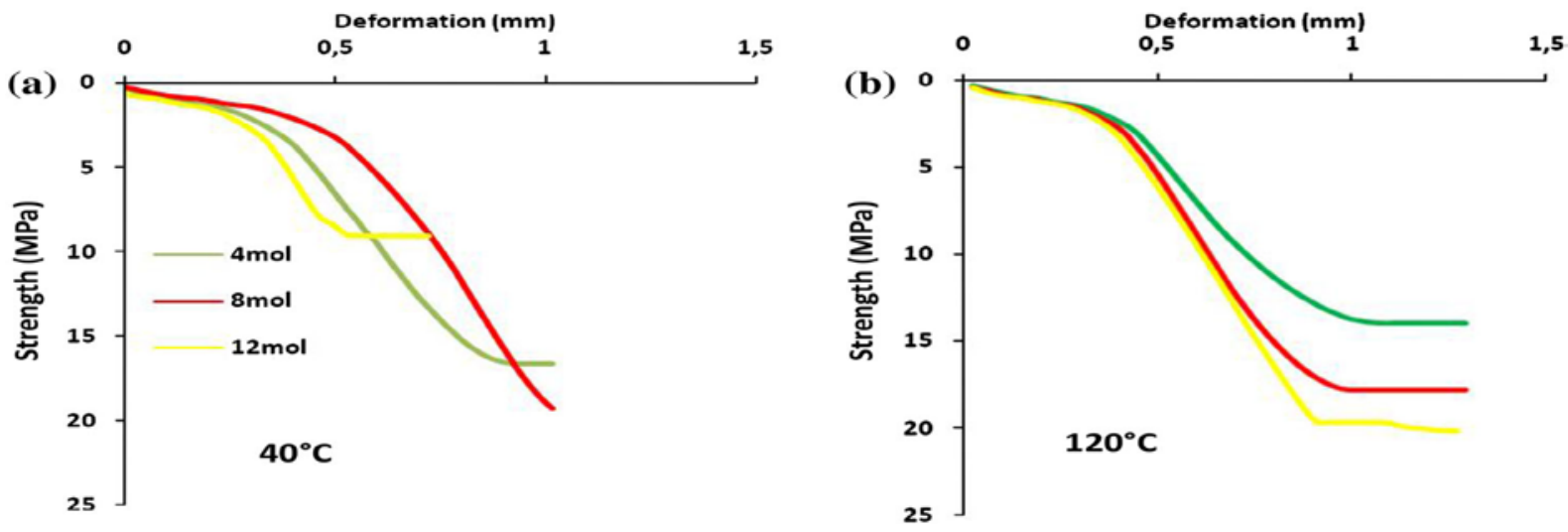

Fig. 3 Stress-strain curves for the Allou Kagne attapulgite clay samples cured at $40^{\circ} \mathrm{C} / 60 \% \mathrm{RH}$ for 28 days (view a \#s 6,14,23) and $120^{\circ} \mathrm{C}$ for 12 hours (view $\mathbf{b} \# \mathrm{~s} 3,11,20$ ). Each sample was made with 4, 8 and $12 \mathrm{M} \mathrm{NaOH}$ solution as a thick paste and then cured

A summary of the strength data for samples cured at 40 and $120^{\circ} \mathrm{C}$ is given in Table 3 . The variability in strength testing of the two cylinder specimens was as low as $3 \%$. As one can see from Fig. 4, compressive strengths ranged from 4.5 to more than $27.1 \mathrm{MPa}$. Although $4.5 \mathrm{MPa}$ is insufficient, a strength of $27 \mathrm{MPa}$ is quite sufficient for bricks. For example, French Standards for solid bricks define different strength classes from 12.5 to $40 \mathrm{MPa}$ [56]. These strengths are in the range of similar samples made with clay soil containing metakaolin $[38,40,51,52,64]$.

Table 3 Summary of the strength data (MPa) for samples cured at $40 \circ \mathrm{C} / 60 \% \mathrm{RH}$ and $120 \circ \mathrm{C}$

\begin{tabular}{|c|c|c|c|c|c|c|}
\hline \multirow[t]{2}{*}{ Temperature $(\circ \mathrm{C})$} & \multirow[t]{2}{*}{ Concentration (mol) } & \multicolumn{5}{|l|}{ Duration (days) } \\
\hline & & 7 & 24 & 28 & 60 & 90 \\
\hline \multirow[t]{3}{*}{40} & 4 & 14.06 & 13.92 & 13.28 & 14.30 & 13.54 \\
\hline & 8 & 15.65 & 13.43 & 15.93 & 16.62 & 16.67 \\
\hline & 12 & 8.45 & 6.40 & 6.65 & 7.61 & 5.36 \\
\hline \multirow[t]{2}{*}{ Temperature $(\circ \mathrm{C})$} & Concentration (mol) & Duration (h) & & & & \\
\hline & & 6 & 12 & 24 & & \\
\hline \multirow[t]{3}{*}{120} & 4 & 8.84 & 13.04 & 14.58 & & \\
\hline & 8 & 4.50 & 18.07 & 24.74 & & \\
\hline & 12 & 6.67 & 21.63 & 27.09 & & \\
\hline
\end{tabular}



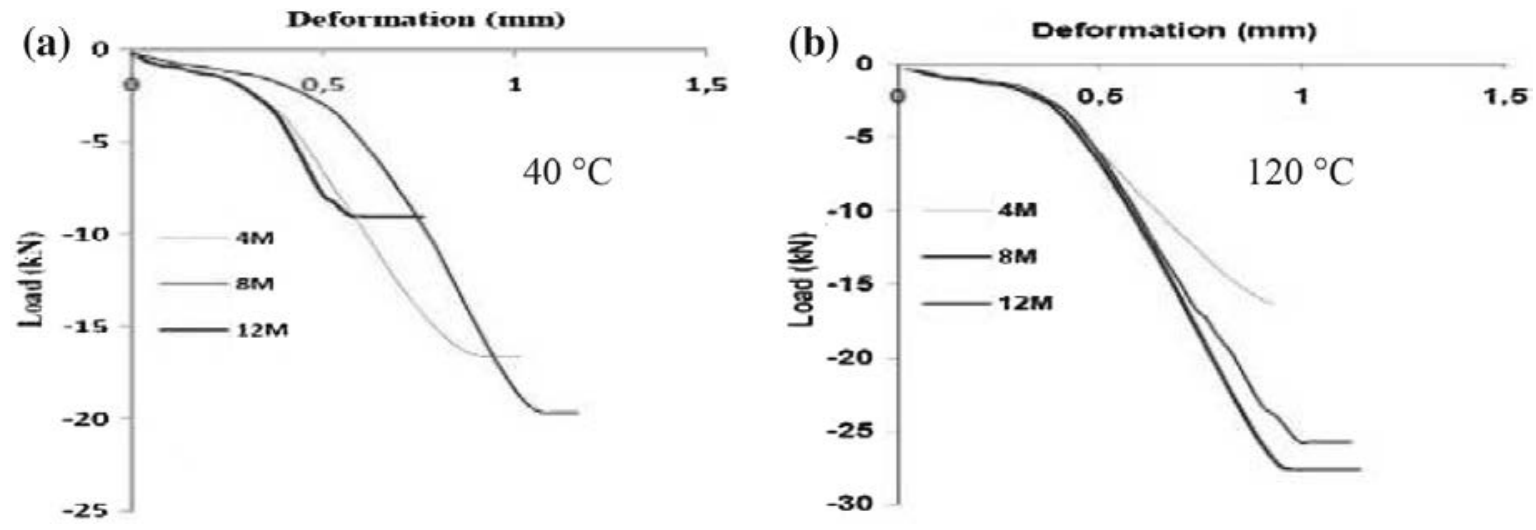

Fig. 4 Stress-strain curves for the Allou Kagne attapulgite clay samples cured at $40^{\circ} \mathrm{C} / 60 \%$ RH for 60 days (view a \#s 6,14,23) and $120^{\circ} \mathrm{C}$ for 24 hours (view $\mathbf{b}$ \#s 3,11,20). Each sample was made with 4, 8 and $12 \mathrm{M} \mathrm{NaOH}$ solution as a thick paste and then cured

In short-term tests (i.e., bricks kept at $120^{\circ} \mathrm{C}$ during 6, 12 and 24 h) (Fig. $3 \mathrm{~b}$ and $4 \mathrm{~b}$ ), compressive strength increases very rapidly. The maximum strength is obtained after $24 \mathrm{~h}$ for $12 \mathrm{M}$ concentrations (27.1 MPa). For all concentrations, strength obtained after $24 \mathrm{~h}$ is the greatest: 14.6 MPa for $4 \mathrm{M}$ concentration, 24.7 MPa for $8 \mathrm{M}$ concentration and 27.1 MPa for $12 \mathrm{M}$ concentration. The lowest strength (4.5 MPa) is obtained with $8 \mathrm{M}$ concentration after $6 \mathrm{~h}$ of conservation.

In long-term tests (i.e., bricks kept at $40^{\circ} \mathrm{C}$ and $60 \% \mathrm{RH}$ during 7, 14, 28, 60, and 90 days) (Fig. 3a and 4a), strength seems to be independent of time. For all periods, strength obtained with $8 \mathrm{M}$ concentration is the greatest $(16.7 \mathrm{MPa})$. For this concentration, strength of $15.8 \mathrm{MPa}$ is obtained after only 7 days of conservation. The lowest strength (6.3 MPa) is obtained with $12 \mathrm{M}$ concentration after 3 months of conservation.

For most of the alkali-activated clay we have tested [1,40,51,52] in similar conditions (concentration, humidity, temperature), long-term strengths are usually the highest. For the attapulgite clay studied here, short-term tests result in greater strength.

\subsection{Durability Tests}

The leaching tests on the $120^{\circ} \mathrm{C}$ cured samples showed that at $24 \mathrm{~h}$, conductivities were very low regardless of the alkali concentration used to make the brick. Conductivity values decreased with time (Table 4), with one day conductivities for all three samples being greater than they are at 7 days. There is a kinetic process (possibly diffusion controlled) that limits the buildup of $\mathrm{Na}$ in solution. There is little $\mathrm{Al}$ or $\mathrm{Si}$ present in the solution, and since these species are essentially insoluble, it is the sodium which accounts for the conductivity. For example, a standard solution of $\mathrm{NaOH}$ in water with a conductivity of $1 \mathrm{mS} / \mathrm{cm}$ contains $\sim 200 \mathrm{ppm} \mathrm{NaOH} \mathrm{[56].}$

The $4 \mathrm{M}$ and $8 \mathrm{M}$ samples have the lowest overall conductivities, whereas the $12 \mathrm{M}$ samples are almost twice as high. This suggests that the amount of $\mathrm{Na}$ in the 4 and $8 \mathrm{M}$ brick reacts nearly completely, whereas the $12 \mathrm{M}$ sample may contain excess $\mathrm{NaOH}$ or soluble sodium silicate which washes out, giving it a higher conductivity and $\mathrm{pH}$. The sodium silicate reacts with clay particles and dissolves part of them, enabling the formation of geopolymers that bind the structure. Nevertheless, all conductivity values are reasonably low, proving that reactions occur during curing and that zeolite-like mineral(s) or geopolymers probably form [46].

Table 4 Results of leaching test of bricks cured at $120^{\circ} \mathrm{C}$ for $12 \mathrm{~h}$ with 4,8 and $12 \mathrm{M}$ of $\mathrm{NaOH}$ used

\begin{tabular}{llc|lc}
\hline Concentration (M) & \multicolumn{2}{c|}{ Measurement at 1 day } & \multicolumn{3}{c}{ Measurement at 7 days } \\
\cline { 2 - 5 } & Conductivity $(\mathrm{mS} / \mathrm{cm})$ & $\mathrm{pH}$ & Conductivity $(\mathrm{mS} / \mathrm{cm})$ & $\mathrm{pH}$ \\
4 & 1.40 & 10.0 & 1.10 & 10.0 \\
8 & 1.70 & 10.0 & 1.60 & 10.5 \\
12 & 2.70 & 11.0 & 2.50 & 11.0 \\
\hline
\end{tabular}

Diop M.B., Molez L., Bouguerra A., Diouf A.., Grutzeck M.W., Arabian Journal for Science Engineering (2014) 39:4351-4361, DOI 10.1007/s13369-014-1007-9 


\subsection{Physical and Chemical Analysis}

SEM observations were carried out after 60 days of curing of the different specimens. Figure 5 a presents the typical microstructure of the attapulgite clay. At high magnifications $(10,000 \times)$, fibres, which have dimensions of several microns in length and 0.1-0.2 $\mu \mathrm{m}$ in width, can be seen. The fibres appear to be arranged in bundles consisting of several straight fibres attached to each other. The fibres were subdivided into closely aligned parallel subunits of a width of $\sim 0.02 \mu \mathrm{m}$. The fiber structure of attapulgite disappeared, changing in a plate-like structure (Fig. 5b). The sample activated with $12 \mathrm{M} \mathrm{NaOH}$ and cured at $40^{\circ} \mathrm{C}$ and, $60 \% \mathrm{RH}$ presents an amorphous microstructure. This can be explained by the transformation of palygorskite, the main mineral of attapulgite clay, into a geopolymer.

X-ray diffraction of attapulgite clay shows (Fig. 6a) the following paragenesis: palygorskite, quartz, calcite, dolomite, hematite, and ankerite. Figure $6 \mathrm{~b}$ presents the $\mathrm{X}$-ray diffraction patterns for the $120^{\circ} \mathrm{C}$ samples cured for 7 days, made with $12 \mathrm{M} \mathrm{NaOH}$ solution. A detailed characterization of the reaction products seems to be quite difficult because of the low crystallinity of the reaction products.

The peak at $22^{\circ}$ is thought to be associated with albite (NaAlSi3O8). Montmorillonite (CaO0.2(AlMg)2SiO10 $(\mathrm{OH}) 24 \mathrm{H} 2 \mathrm{O})$, larnite (Ca2SiO4), fosterite $(\mathrm{Mg}, \mathrm{Fe}) 2 \mathrm{SiO} 4$, hydroxylapatite (Ca5(PO4)3 (OH), stilbite $(\mathrm{Ca}, \mathrm{Na}) 1,3(\mathrm{Si}, \mathrm{Al}) 9 \mathrm{O} 188 \mathrm{H} 2 \mathrm{O}$, dolomite $\left(\mathrm{CaMg}(\mathrm{CO} 3)_{2}\right)$, and calcite $(\mathrm{CaCO} 3)$ are present with the $12 \mathrm{M}$ solution cured 7 days at $120^{\circ} \mathrm{C}$. It was noted that geopolymers were also present because of the reduction in the amount of original materials, and also because of their being amorphous; furthermore, they would not be detected in a coherent fashion by X-rays diffraction due to amorphous nature.
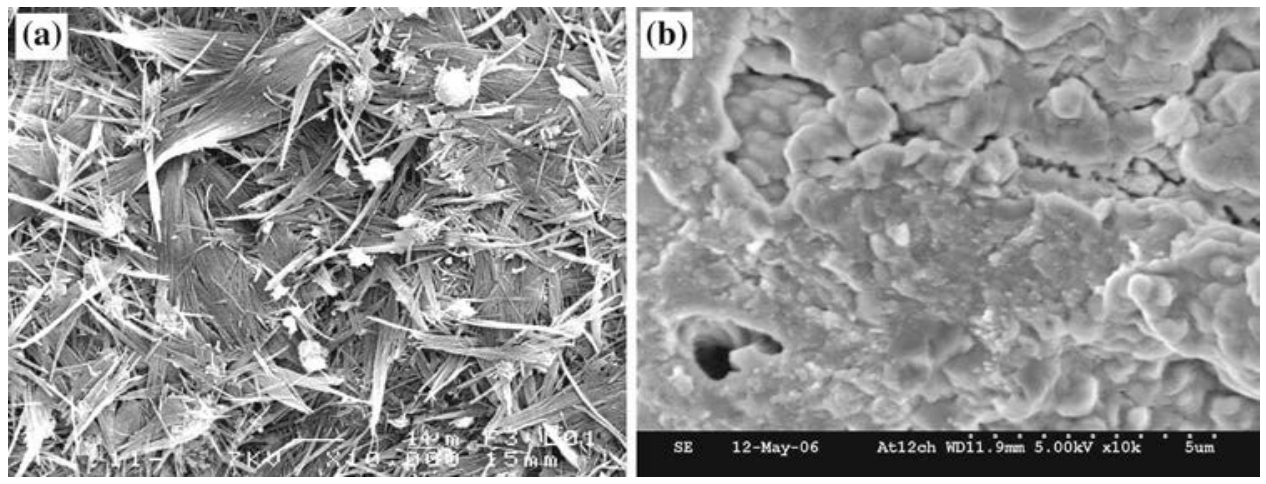

Fig. 5 Views represent typical microstructures of Allou Kagne attapulgite clay. Views (a) show that the phases present are fibers of palygorskite. Views (b) represent brick samples made with $12 \mathrm{M} \mathrm{NaOH}$ solution and cured for 90 days at $40^{\circ} \mathrm{C}$ and $60 \% \mathrm{RH}$
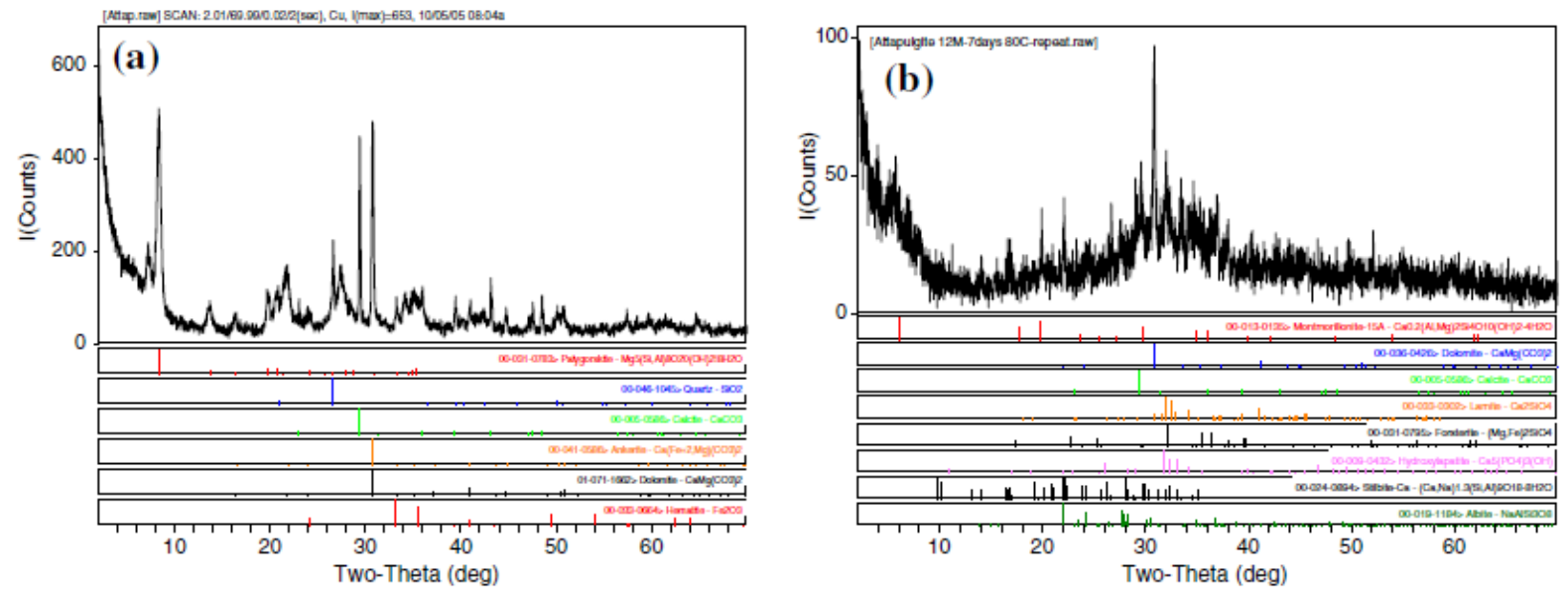

Fig. 6 X-ray diffraction pattern of attapulgite clay and alkali activated clay. (a) Attapulgite clay. $9^{\circ}$ peak is associated with palygorskite. (b) Alkali activated clay $\left(12 \mathrm{M}\right.$ concentration at $120^{\circ} \mathrm{C}$ for 7 days). Phases are much more amorphous 


\section{Discussion}

For samples cured at $120^{\circ} \mathrm{C}$, regardless of the concentration of $\mathrm{NaOH}$ used, $24 \mathrm{~h}$ of curing gave the best compressive strength ( $+39 \%$ between 12 and $24 \mathrm{~h}$ for $8 \mathrm{M}$ concentration, and $+23 \%$ for $12 \mathrm{M}$ concentration) . This can be explained by the fact that, with increased temperature, the reaction between the alkali solution and the clay (dehydroxylation, disintegration of the solid network and polycondensation of alumosilicate polymers) has taken place very early. After $24 \mathrm{~h}$ of curing, the hydrated phases that form are more likely geopolymeric because the bulk composition of the starting material falls within a compositional range [44] typical (35-65\% $\mathrm{SiO} 2,35-65 \% \mathrm{Al}_{2} \mathrm{O} 3,35-65 \% \mathrm{Na} 2 \mathrm{Oin}$ weight) for geopolymers. Geopolymers enhance the stability of attapulgite clay. They are able to bond with each other and form a solid that is much more resistant to softening and deformation during annual wet/dry cycles. Minerals that form first, in the presence of abundant water, will become less hydrated and undergo phase transitions as a result of diagenesis. If placed in an aggressive environment, like an acidic $\mathrm{pH}$ one, they will also dissolve. In neutral and alkaline environments, however, they are very insoluble. Geopolymers will change with geological time when buried. However, this change is nearly imperceptible when they are exposed to heat and humidity at the surface. The type of geopolymer that forms during the manufacture of the afore-mentioned brick is somewhat temperature dependent. On occasion, the initially formed geopolymer will change into another one that is more stable. This is a problem associated with nucleation and grain growth, or polymer growth, from supersaturated solutions, and is similar to what happens during diagenesis. Early formed geopolymers are often the least stable, converting to a more stable form after a few hours or days of curing (geopolymerization time). This makes it mandatory for those making bricks with this method (especially at $120^{\circ} \mathrm{C}$ ) to test their strength versus time to check whether a disruptive phase change, which could reduce performance by introducing shrinkage/expansion cracks, occurs. For instance, if the specimen is initially cured at $120^{\circ} \mathrm{Cand} 0 \% \mathrm{RH}$ for $12 \mathrm{~h}$ and then left outside at $40^{\circ} \mathrm{C}$ and $20 \% \mathrm{RH}$ for 1 month, some changes in the geopolymer may occur. However, these changes are progressive and low in terms of strength for all the materials tested. If they occur, samples should not be cured longer than is necessary to achieve initial maximum strength.

However, in short-term tests (6, 12, 24 h), $12 \mathrm{M}$ concentration gave the overall maximum strength (27.1 MPa). For long-term tests (7-90 days), $8 \mathrm{M}$ concentration gave the maximum strength (16.7 MPa) obtained after 3 months, and $12 \mathrm{M}$ concentration gave the lowest strength (5.4 MPa) obtained after 90 days. This is what might be expected, since the more the concentration of the alkali solution increases, the more small reactable silicate and aluminate species will dissolve in the solution, and the more sodium aluminosilicate precursors will form the ideal ratio to give polysialatedisoloxo $\left(\mathrm{SiO}_{2} / \mathrm{Al}_{2} \mathrm{O}_{3}=6\right)$. However, increase in the concentration of $\mathrm{NaOH}$ (e.g., to $12 \mathrm{M}$ or $15 \mathrm{M}$ ) will not cause a continuous increase in strength, rather it will cause more sodium-rich phases to form what may not be considered as insoluble. This will increase solubility and possibly have a negative effect on durability $[41,65,66]$. This is certainly what we observed with $12 \mathrm{M}$ alkali-activated attapulgite clay: in long-term tests, $12 \mathrm{M}$ gave the lowest strength. In short-term tests, the curing temperature is $120^{\circ} \mathrm{C}$, and it influences alkali activity. Alkali activity depends upon temperature: a higher temperature leads to a more complete chemical reaction, and thus shifts the maximum concentration of $\mathrm{NaOH}$ that helps achieve the best strength.

An amorphous vitreous phase is revealed in the X-ray diffraction pattern of activated clay at the site of an intensity hump. The larger the hump, the more prevalent are the vitreous and/or poorly crystallized phases. These poorly crystallized phases may be the cementing phases that give the sample their strength [67]. Even though their presence is not obvious in the X-ray diffraction patterns [68], the formed cementing phases are more likely geopolymeric in nature $[11,18,69]$. The presence of $\mathrm{CaCO} 3$ (calcite, dolomite, etc.), which produces $\mathrm{CaO}$ upon calcination, has a negative effect on strength [70,71]. The alkaline activation of clay with concentrated $\mathrm{NaOH}$ solutions produces an amorphous material with excellent cementing properties in terms of mechanical strength [19].

Strength development is dependent on temperature and length of curing, as well as alkali concentration, fineness, crystallinity, and composition of the raw materials [25,38,65,72,73]. For samples cured at $120^{\circ} \mathrm{C}$ for $24 \mathrm{~h}$, an elevated temperature seems to impart the best mechanical properties to the samples, regardless of the concentration of $\mathrm{NaOH}$ solution used to make the sample. It is also notable that the strength gained at any given

Diop M.B., Molez L., Bouguerra A., Diouf A.., Grutzeck M.W., Arabian Journal for Science Engineering (2014) 39:4351-4361, DOI 10.1007/s13369-014-1007-9 
time is directly proportional to the concentration of $\mathrm{NaOH}$ used to make the sample. For reactions carried out at lower temperatures, strengths of samples cured in the $40^{\circ} \mathrm{C}$ and $60 \% \mathrm{RH}$ chamber seem not to be time dependent for all concentrations. The chemical reaction seems to have ended before 7 days.

Leaching results indicate that there is a kinetic process (possibly diffusion controlled) that limits the buildup of $\mathrm{Na}$ in solution. There is little $\mathrm{Al}$ or $\mathrm{Si}$ present in the solution because their compounds are essentially insoluble, and it is the sodium which accounts for conductivity. For example, a standard solution of $\mathrm{NaOH}$ in water with a conductivity of $1 \mathrm{mS} / \mathrm{cm}$ contains $200 \mathrm{ppm} \mathrm{NaOH}$ [56]. The low conductivity obtained for $4 \mathrm{M}$ and $8 \mathrm{M}$ samples suggests that the Na component of the 4 and $8 \mathrm{M}$ brick reacts nearly completely. In contrast, the $12 \mathrm{M}$ sample may contain an excess of $\mathrm{NaOH}$. Thus, the sodium silicate is still soluble and washes out, giving a higher conductivity. Nevertheless, all conductivity values are reasonably low, which indicates that reactions occur during curing and that geopolymer-like mineral(s) probably form [57]. The moderate $\mathrm{pH}$ confirms the formation of silicate minerals of some type. These values are in line with those obtained when natural geopolymers are placed in water. Sodium does not leach from these minerals to any great extent.

XRD analysis shows that alkali activation leads to the disappearance of the palygorskite (peak at 9 ). This transformation of palygorskite into a geopolymer should produce a more durable material. Clay minerals react slowly with alkaline solutions [14,74], but here, the mechanical strength in short-term tests is greater than that obtained in long-term tests due to the effect of reaction temperatures.

The strengths and leachabilities of the samples are similar to those of alkali-activated metakaolinite samples, which usually run at about $3 \mathrm{MPa}$ and which have a $\mathrm{pH}$ of about 10 and a conductivity of $2-3 \mathrm{mS} / \mathrm{cm}[14,56,57]$. These results are consistent with those obtained with Senegalese kaoliniterich tuff [40] and Niemenike clay containing kaolinite [52].

The ability to make a brick with these characteristics is rather exciting because of its implications and the potential impact on the nature of sun-dried brick making in developing countries [75]. 


\section{Conclusions}

The work reported here is an extension of previous work, and has shown that Allou Kagne's attapulgite clay can be used to make bricks without any thermal pre-treatment. There are scattered references to rather slow reactions of clay caustic $[14,75]$ that tend to reinforce current thinking that the reactivity of clays must be increased by heating them to $500-700^{\circ} \mathrm{C}$ (i.e., dehydroxylating them) to increase their reactivity and make their use viable in a real-time frame [45]. However, the outcome of the work on the Allou Kagne attapulgite clay was unexpected.

Using the technique described, a wooden mold and a mix of clay and seawater (if commercially produced silicates are not available) are sufficient to fabricate good quality blocks. Locally available materials can be tested with different amounts of $\mathrm{NaOH}$ as mixing solution and cured as a function of temperature to determine the optimum concentrations of $\mathrm{NaOH}$. As the reaction of the clay with $8 \mathrm{M} \mathrm{NaOH}$ will continue for a long time at 40 and $80^{\circ} \mathrm{C}$, it seems probable that curing could take place under a heavy tarp in the sun, a situation available to most villagers living in equatorial zones where temperature and humidity are high. It is also proposed that a simple manual press might be used to make full-sized bricks. The mixture is quite plastic much like ball clay and can be extruded [76].

From the present work, it is recommended that $8 \mathrm{M} \mathrm{NaOH}$ can be used as a realistic compromise between strength and cost, as the best strength $(15.65 \mathrm{MPa})$ is obtained only after one week conservation at $40^{\circ} \mathrm{C}$ and 60 $\%$ RH.

For short-term tests (6, 12 and $24 \mathrm{~h}), 8 \mathrm{M} \mathrm{NaOH}$ and $24 \mathrm{~h}$ of conservation give a realistic compromise (24.74 $\mathrm{MPa})$. If a stronger brick is needed, the strength can be enhanced (27.0 MPa) using $12 \mathrm{M} \mathrm{NaOH}$ for $24 \mathrm{~h}$ at $120^{\circ}$ Cand0\% RH.

A low temperature process to create durable bricks can be developed according to the needs of the community. Brick made with this technology is well suited to areas where other forms of energy are not available and bricks can be cured in the sun. The process does not generate chemical pollutants and can use by-product materials, such as industrial waste and mining waste, assisting in dealing with environmental problems.

In addition to its value for developing countries, the process has implications all over the world where clean technology is an important consideration. 


\section{References}

1. Diop, M.B.; Kane, A.D.; Diassé, A.; Ndiaye, A.A.; Gomina, M.; Bouguerra, A.: Valorisation des rejets de traitement d'attapulgite de allou Kagne en boue de forage. caractérisation et étude expérimentale Journal Société Ouest Africaine de Chimie Soachim, 11 année, No. 21, pp. 19-27, Publication biannuelle, ISSN: 0796-6687 (2006)

2. Guggenheim, S.; Martin, R.T.: Definition of clay and clay mineral: joint report of the AIPEA nomenclature and CMS nomenclature committees. Clays Clay Miner. 43(2), 255-256 (1995)

3. Brindley, G.W.: Clay mineral nomenclature (report of discussions and recommendations of the clay mineral society nomenclature committee, 1965-6). Am. Miner. 6, 437-440 (1965)

4. Ehlers, E.G.; Blatt, H.: Petrology, igneous, sedimentary, and metamorphic. W.H. Freeman and Company, San Francisco (1982). ISBN 0-7167-1279-2

5. Hillier, S.: Clay mineralogy. In: Middleton, G.V.; Church M.J.; Coniglio M.; Hardie L.A.; Longstaffe, F.J. (eds.) Encyclopedia of sediments and sedimentary rocks, pp. 139-142. Kluwer Academic Publishers, Dordrecht (2003)

6. Hollo, N.: Warm House Cool House Inspirational Designs for Low-Energy Housing, 2nd revised edn, 272 pp. Choice Books, Sydney (2011)

7. Edwards, R.: Mud Brick Techniques by Buy Books online: Mud Brick Techniques, Ron Edwards, 1st edn, 48 p. Published Kuranda [Qld.]. The Rams Skull Press (1990). ISBN: 0909901988

8. Mobbs, M.: Sustainable House, 2nd edn, 288 pp. Choice Books House, Sydney (2010). ISBN: 9781920705527

9. Wirth, L.: Attapulgites du Sénégal Occidental Rapport No. 6 (1968)

10. Bradley, W.F.: The structural scheme of attapulgite. Am. Miner. 25, 405 (1940)

11. Davidovits, J.: Geopolymers and geopolymeric materials. J. Therm. Anal. Cal. 35(2), 429-441 (1989). doi:10.1007/ BF01904446

12. Cioffi, R.; Maffucci, L.; Santoro, L.: Optimization of geopolymer synthesis by calcination and polycondensation of a kaolinitic residue. Resour. Conserv. Recycl. 40, 27-38 (2003)

13. Duxson, P.; Fernández-Jiménez, A.; Provis, J.; Lukey, G.; Palomo, A.; Deventer, J.: Geopolymer technology: the current state of the art. J. Mater. Sci. 42, 2917-2933 (2007)

14. Berg, L.G.; Remiznikova, V.I.; Vlasov, V.V.: Reaction of kaolinite with caustic soda. Khimiya i Khimicheskaya Teknol. 8(2), 181-185 (1965)

15. Elimbi, A.; Tchakoute, H.K.; Njopwouo, D.: Effects of calcination temperature of kaolinite clays on the properties of geopolymer cements. Constr. Build. Mater. 25(6), 2805-2812 (2011). ISSN 0950-0618. doi:10.1016/j.conbuildmat.2010.12.055

16. Buchwald, A.; Hohmann, M.; Posern, K.; Brendler, E.: The suitability of thermally activated illite/smectite clay as raw material for geopolymer binders. Appl. Clay Sci. 46(3), 300-304 (2009). doi:10.1016/j.clay.2009.08.026. ISSN: 0169-1317

17. Siemer, D.D.; Grutzeck, M.W.; Scheetz, B.E.: Comparison of materials for making hydroceramic waste forms. Ceram Trans 2000. 107, 161-167 (2000) (Environmental Issues and Waste Management Technologies in the Ceramic and Nuclear Industries V)

18. Grutzeck, M.W.; Siemer, D.D.: Zeolites synthetized from Class F fly ash and sodium aluminate slurry. J. Amer. Ceram. Soc. 80(9), 2449-2453 (1997)

19. Palomo, A.; Grutzec, M.W.; Blanco, M.T.: Alkali-activated fly ashes. A cement for the future. Cem. Con. Res. 29, 1323-1329 (1999)

20. Yost, J.; Radli'nska, A.; Ernst, S.; Salera, M.: Structural behavior of alkali activated fly ash concrete. Part 1: mixture design, material properties and sample fabrication Materials and Structures, pp. 1-13. Springer, Netherlands (2012)

21. Bernal, S.; Rodríguez, E.; Mejia de Gutiérrez, R.; Provis, J.; Delvasto, S.: Activation of Metakaolin/Slag Blends using Alkaline Solutions Based on Chemically Modified Silica Fume and Rice Husk Ash Waste and Biomass Valorization, vol. 3, pp. 99-108. Springer, Netherlands (2012)

22. Takeda, H.; Hashimoto, S.; Iwata, T.; Honda, S.; Iwamoto, Y.: Fabrication of bulk materials with zeolite from coal fly ash. J. Mater. Cycles Waste Manag. 14, 403-410 (2012)

23. Matlob, A.S.; Kamarudin, R.A.; Jubri, Z.; Ramli, Z.: Using the response surface methodology to optimize the extraction of silica and alumina from coal fly ash for the synthesis of zeolite Na-A. Arab.J.Sci.Eng. 37(1), 27-40 (2012)

24. Phair, J.W.; Van Deventer, J.S.J.: Effect of silicate activator $\mathrm{pH}$ on the leaching and material characteristics of waste-based geopolymers. Miner. Eng. 14(3), 289-304 (2001)

25. Cheng, T.W.; Chiu, J.P.: Fire-resistant geopolymer produced by granulated blast furnace slag. Miner. Eng. 16, 205-210 (2003)

26. Temuujin, J.; Rickard, W.; Lee, M.; van Riessen, A.: Preparation and thermal properties of fire resistant metakaolin-based geopolymer-type coatings. J. Non-Cryst. Solids. 357(5), 1399- 1404 (2011)

27. Xu, H.; Van Deventer, J.S.J.: The geopolymerisation of aluminosilicate minerals. Int. J. Miner. Process. 59(3), 247-266 (2000)

28. Davidovits, J.: Geopolymer chemistry and sustainable Development. The Poly(sialate) terminology: a very useful and simple model for the promotion and understanding of green-chemistry. In: Davidovits, J. (ed.) Proceedings of the World Congress Geopolymer (2005)

29. Davidovits, J.; Comrie, D.C.; Paterson, J.H.; Ritcey, D.J.: Geopolymeric concretes for environmental protection. Concrete Int. 12, 30-39 (1990)

30. Davidovits, J.: Method for bonding fiber reinforcement on concrete and steel structures and resultant products. US Patent No. 5925449 (1999)

31. Davidovits, J.; Buzzi, L.; Rocher, P.; Gimeno, D.; Marini, C.; Tocco, S.: Geopolymeric cement based on low cost geologic materials. Results from the european research project geocistem. In: Davidovits, J.; Davidovits, R.; James, C. (eds.) Proceedings of the 2nd International Conference on Geopolymer '99, June 30-July 2, pp. 83-96. Saint Qunentin, France (1999)

32. De Silva, P.; Sagoe-Crenstil, K.; Sirivivatnanon, V.: Kinetics of geopolymerization: role of Al2O3 and SiO2. Cement Concrete Res. 37, 512-518 (2007)

33. Xu, H.; Van Deventer, J.S.J.: Geopolymerisation of multiple minerals. Miner. Eng. 15, 1131-1139 (2002)

34. Phair, J.W.; Van Deventer, J.S.J.: Effect of the silicate activator $\mathrm{pH}$ on the microstructural characteristics of waste-based 
geopolymers. Int. J. Miner. Process. 66, 121-143 (2002)

35. Komnitsas, K.; Zaharaki, D.; Perdikatsis, V.: Geopolymerization of low calcium ferronickel slags. J. Mater. Sci. 42, 3073-3082 (2007)

36. Panias, D.; Giannopoulou, I.; Perraki, T.: Effect of synthesis parameters on the mechanical properties of fly ash-based geopolymers. Colloids Surf. A Physicochem. Eng. Asp. 301, 246-254 (2007)

37. Arikan,M.;Sobolev,K.;Ertün,T.;Ye ginobali,A.;Turker,P.:Properties of blended cements with thermally activated kaolin, Constr. Build. Mater. 23, 62-70 (2009)

38. Heah, C.Y.; Kamarudin, H.; Mustafa Al Bakri, A.M.; Binhussain, M.; Luqman, M.; Nizar, I.K.; Ruzaidi, C.M.; Liew, Y.M.: Effect of curing profile on kaolin-based geopolymers. Physic Procedia 22, 305-311 (2011)

39. Tchakoute, H.; Elimbi, A.; Mbey, J.A.; Ngally Sabouang, C.; Njopwouo, D.: The effect of adding alumina-oxyde to metakaolin and volcanic ash on geopolymer products: a comparative study. Constr. Build. Mater. 35, 960-969 (2012)

40. Diop, M.B.; Grutzeck, M.W.: Low temperature process to create brick. Constr. Build. Mater. (2008a). doi:10.1015/j.conbuilmat. 2007.03.004

41. Thokchom, S.; Ghosh, P.; Ghosh, S.: Effect of Na2O content on durability of geopolymer pastes in magnesium sulfate solution. Can. J. Civil Eng. 39(1), 34-43 (2012a)

42. Lizcano, M.; Kim, H.; Basu, S.; Radovic, M.: Mechanical properties of sodium and potassium activated metakaolin-based geopolymers. J. Mater. Sci. 47, 2607-2616 (2012)

43. Sivapullaiah, P.; Sankara, G.; Allam, M.: Mineralogical changes and geotechnical properties of an expansive soil interacted with caustic solution. Environ. Earth Sci. 60, 1189-1199 (2010)

44. Breck, D.W.: Zeolite Molecular Sieves. Wiley, New York (1974)

45. Rahier, H.; Wullaert, B.; Van Mele, B.: Influence of the degree of dehydroxylation of Kaolinite on the properties of aluminosilicate glasses. J. Therm. Anal. Calorimetry. 62(2), 417-427 (2000)

46. Bich, Ch.; Ambroise, J.; Pera, J.: Influence of degree of dehydroxylation on the pozzolanic activity of metakaolin. Appl. Clay Sci. 44(3-4), 194-200 (2009)

47. Sarikaya, Y.; Önal, M.; Baran, B.; Alemdarolu, T.: The effect of thermal treatment on some of the physicochemical properties of a bentonite. Clays Clay Miner. 48, 557-562 (2000)

48. Tan Ö., Yılmaz, L.; Zaimolu, S.: Variation of some engineering properties of clays with heat treatment. Mater. Lett. 58, 1176-1179 (2004)

49. Wang, M.R.; Jia, D.C.; He, P.G.; Zhou, Y.: Influence of calcination temperature of kaolin on the structure and properties of final geopolymer. Matter. Letter. 64, 2551-2554 (2010)

50. Liew, Y.M.; Kamarudin, H.; Mustafa Al Bakri, A.M.; Luqman, M.; Khairul Nizar, I.; Ruzaidi, C.M.; Heah, C.Y.: Processing and characterization of calcined kaolin cement powder. Constr. Build. Mater. 30, 794-802 (2012)

51. Diop, M.B.; Grutzeck, M.W.: Sodium silicate activated clay brick. Bull. Eng. Geol. Environ. (2008b). doi:10.1007/ s10064-008-0160-3

52. Diop, M.B.; Grutzeck, M.W.; Molez, L.: Comparing the performances of bricks made with natural clay and clay activated by calcination and addition of sodium silicate. Appl. Clay Sci. 54(2), 172-178 (2011). doi:10.1016/j.clay.2011.08.005. ISSN 0169-1317

53. Dyer, A.: An Introduction to Zeolite Molecular Sieves. Wiley, New York (1988)

54. Grutzeck, M.W.; Kwan, S., DiCola, M.: Zeolite formation in alkali-activated cementitious systems. Cem. Concrete. Res. 34(6), 949- 955 (2004)

55. Bao, Y.; Kwan, S.; Siemer, D.D.; Grutzeck, M.W.: Binders for radioactive waste forms made from pretreated calcined sodium bearing waste (SBW). J. Mater. Sci. 39(2), 481-488 (2004)

56. Bao, Y.; Grutzeck, M.W.; Jantzen, C.M.: Preparation and properties of hydroceramic waste forms made with simulated Hanford low-activity waste. J. Am. Ceram. Soc. 88(12), 3287-302 (2005)

57. Bao, Y.; Grutzeck, M.W.: General recipe and properties of a four inch hydroceramic waste form. In: Ceramic Transactions, vol. 176 (Environmental Issues and Waste Management Technologies in the Ceramic and Nuclear Industries XI), pp. 63-74. American Ceramic Society, Westerville (2006)

58. Ma, Y.; Hu, J.; Ye, G.: The effect of activating solution on the mechanical strength, reaction rate, mineralogy, and microstructure of alkali-activated fly ash. J. Mater. Sci. 47, 4568-4578 (2012)

59. Martin Vivaldi, J.L.; Linares Gonzalez, J.: A random intergrowth of sepiolite and attapulgite. Clays Clay Minerals. 9, 592-602 (1960)

60. Kulbicki, G.; Grim, R.E.: A new method of thermal dehydration studies of clay minerals. Mineral. Mag. 32(244), 60-61 (1959)

61. Frost, R.L., Ding, Z.: Controlled rate thermal analysis and differential scanning calorimetry of sepiolites and palygorskites. Thermochim. Acta. 397(1-2), 119-128 (2003). doi:10.1016/ S0040-6031(02)00228-9. ISSN: 0040-6031

62. Singer, A.; Kirsten, W.; Bühmann, C.: Fibrous clay minerals in the soils of Namaqualand. South Africa Charact. Form. Geoderma. 66(1-2), 43-70 (1995). doi:10.1016/0016-7061(94)00052-C. ISSN: 0016-7061

63. ASTM C1285-02: Standard test methods for determining chemical durability of nuclear, hazardous, and mixed waste glasses and multiphase glass ceramics: the product consistency test (PCT), American Society for the Testing of Materials ASTM International, 100 Barr Harbor Drive, PO Box C700, West Conshohocken, PA, 194282959, USA (2008)

64. Heah, C.Y.; Kamarudin, H.; Mustafa Al Bakri, A.M.; Binhussain, M.; Luqman, M.; Nizar, I.K.; Ruzaidi, C.M.; Liew, Y.M.: Effect of mechanical activation on kaolin-based geopolymers. Adv. Mater. Res. 479-481, 357-361 (2012a)

65. Thokchom, S.; Mandal, K.; Ghosh, S.: Effect of Si/Al ratio on performance of fly ash geopolymers at elevated temperature. Arab. J. Sci. Eng. 37, 977-989 (2012b)

66. Gjørv, O.E.: Durability of concrete structures. Arab. J. Sci. Eng. 36(2), 151-172 (2011). doi:10.1007/s13369-010-0033-5

67. Duchesne, J.; Duong, L.; Bostrom, T.; Frost, R.: Microstructure Study of Early In Situ Reaction of Fly Ash Geopolymer Observed by Environmental Scanning Electron Microscopy (ESEM) Waste And Biomass Valorization, vol. 1, pp. 367-377. Springer, Netherlands (2010)

68. Choi, S.; Jun, S.; Oh, J.; Monteiro, P.: Properties of alkali-activated systems with stone powder sludge. J. Mater. Cycles Waste Manag. 12, 275-282 (2010) 
69. Brough, A.R.; Atkinson, A.: Sodium silicate-based, alkali-activated slag mortars: Part I. Strength Hydration Microstruct. Cement Concrete Res. 32(6), 865-879 (2002)

70. Mostafa N.Y.; Mohsen, Q.: Investigating the possibility of utilizing low kaolinic clays in production of geopolymer bricks. Ceram. Silica 54(2), 160-168 (2010)

71. Zhang, Z.; Wang, H.; Yao, X.; Zhu, Y.: Effects of halloysite in kaolin on the formation and properties of geopolymers. Cement Concrete Compos. 34, 709-715 (2012)

72. Heah, C.Y.; Kamarudin, H.; Mustafa Al Bakri, A.M.; Bnhussain, M.; Luqman, M.; Nizar, I.K.; Ruzaidi, C.M.; Liew, Y.M.: Study on solids-to-liquid and alkaline activator ratios on kaolin-based geopolymers. Constr. Build. Mater. 35, 912-922 (2012b)

73. Nuruddin, F.; Memon, F.A.; Khan, S.; Shafiq, N.; Ayub, T.: Effect of salient parameters on fresh properties and compressive strength of self-compacting geopolymer concrete (2012). http://eprints.utp. edu.my/8557/

74. Sazhin, V.S.; Pankeeva, N.E.: Interaction of kaolinite with sodium hydroxide solutions. Ukrains'kii Khemichnii Zhurnal. 33(5), $528-530(1967)$

75. Leghrieb, Y.; Mitiche, R.; Bentebba, M.; Djouhri, M.; Kriker, A.: The manufacture of raw brick from the Saharan sand-based mortar of Ouargla (located in the Septentrional Sahara, Algeria) for use in Arid Regions. Arab. J. Sci. Eng. 37, 2149-2161 (2012)

76. Diop, M.B.; Jauberthie, R.; Melinge, Y.; Estelle, P.; Lanos, C.: Valorisation des tufs volcaniques acides du Sénégal dans les mortiers: durabilité et mise en forme. C., XXIII ième rencontres Universitaires de Génie Civil ville et Génie Civil (2005) 